\title{
Interplay of Agriculture Deterioration and Poverty Incident
}

\author{
Elgilany Ahmed*, Jamalludin Sulaiman, Saidatulakmal Mohd
}

School of Social Sciences, University Sains Malaysia, Pulau, Penang, 11800, Malaysia

\begin{abstract}
In Sudan agriculture is considered to be the leading economic sector forming typically over $40 \%$ of the GDP has lost much ground with a drop of its GDP share to 33\% in 2007. Northern Sudan as one of the most important agricultural region is characterized by low and erratic rainfall and limited arable land. Agriculture in this district provides an employment for about $70 \%$ of population. More dramatic is the deterioration in the contribution of agriculture to the country's exports, declining to about 3\% in 2007 down from an average of $74 \%$ in the period 1996-1998. Further, a large portion (83\%) of Sudan's rural people today lives in highly vulnerable livelihood and degraded environments. This situation affected agricultural productivity severely through greater frequency of yield-diminishing. This study aims to assess the crop productivity deterioration to the poverty incident in rural area. In tracing differences in agricultural yield and returns, detailed calculations from the collected data were made to estimate the per capita rural income from agricultural activities in northern Sudan. The results suggest that the potential impacts of low yield and yield volatility especially in the conventional farming system extremely causes poverty incident in northern Sudan.
\end{abstract}

Keywords Agriculture Dwindling, Rural Poverty Incident, Crop Yields

\section{Introduction}

Sudan's economic structure has undergone a major shift over the past two decades (DTIS, 2008), the main drivers being oil discovery at the turn of this Century and expansion in services. An overwhelming proportion of the nearly two-thirds of the Sudanese who live in rural areas depend on agriculture for their livelihood. About $70 \%$ of the labor force is principally employed in agricultural sector. It is evident that in the foreseeable future the welfare of Sudan's population, especially of the poor who are largely located in rural areas, will to a substantial degree depend on the performance of the agricultural sector (UNDP, 2004). Agriculture has almost consistently been disadvantaged in public allocations to various economic sectors (Elbashier and Faki, 2006). Its allocations are both meager and dwindling: from $3.4 \%$ to $1.6 \%$ during 2000 to 2005 (by more than $50 \%$ ). The actual share of agriculture in the total development expenditure varied from $8 \%$ to $44 \%$ over the period 2000 to 2005 , but the trend is irregularly increasing. Higher shares were allotted to agriculture within actual expenditure on the overall national development programs ranging from $21 \%$ to $46 \%$; yet also with irregular distribution among years (Faki et al, 2009). Agricultural production in Sudan is hampered by high

* Corresponding author:

elgilanya@yahoo.com (Elgilany Ahmed)

Published online at http://journal.sapub.org/ijaf

Copyright (C) 2012 Scientific \& Academic Publishing. All Rights Reserved production costs especially the irrigated one, excessive taxation particularly for livestock, high costs of provision of services, and charges that are not connected with the provision of any services. This paper aims to assess the interrelation between agricultural deterioration and poverty incident in rural area. Finally, economic activities in public and private sectors, development interventions and commodity movement have been quite restricted. Under such a situation agricultural constraints and poverty incident would obviously be expected to escalate. The main findings of this paper indicated strong relationship between the agricultural diminishing and poverty incidence in rural area. Accordingly, the research seeks to draw a road map of agricultural reforms, State policies and public investments in agriculture.

\section{Methodology}

This study aimed to cover the main three agricultural production domains namely: traditional rain-fed, mechanized rain-fed and irrigated farms overall the country States. The study is based on a field survey data involved direct interviews using a structured questionnaire with detailed information on agricultural activities and poverty measurement-related variables. The data is subjected to analyses on crop yield, poverty line construction and welfare distribution. The income component analysis is carried out that allowed netting out the role of agriculture in poverty generation. Secondary data also used from their relevant sources. 
The collected rural agricultural information included: a delineation of the crop yields' diminishing and poverty incident over the State's agricultural sectors are regarded the main objective of this research, some household agricultural activities beside some other socioeconomic information. The research traced the human poverty index (HPI) assessment obtained recently (2009) by Agricultural Economics and Policy Research Centre (AEPRC) in Sudan. Using the mathematical property of the HPI a distributive device that achieves regional equity was also derived. Since agriculture is the main source of livelihood for the majority of the people in the Sudan, the poverty levels are largely shaped by the conditions of agriculture. In this respect the level of use of natural resources and the associated pressures on land have been illustrated within their space and time dimensions that has close relation to the spread of poverty. In tracing differences in the agricultural situation, detailed calculations from available data were made to estimate average per capita rural income from agriculture and derive poverty levels related to these incomes in each of the 15 northern sates based on data availability at the state level. Further, for highlighting possible interventions for improvement, crop yield and farm income are derived by the type of agricultural activity in different states. Moreover, the important association between the spatial distribution of agricultural incomes and land productivity of crops is manifested by the analysis of time-series crop yields in different states. Yield gap analysis between research and farmers' yields is further conducted to illustrate the potential that exists to boost productivity levels. To verify the relationship between crop yield instability and poverty incident the research focused on a household budget survey that conducted in four selected states based on their poverty levels.

\section{Results and Discussion}

\subsection{Prevalent Farming Systems in Sudan}

Sudan's farming systems are commonly classified into three major categories, namely irrigated, mechanized rainfed and traditional rain-fed systems. Currently, the potential of arable land under utilizing is about $24 \%$. Only $18 \%$ of that is under intensive irrigated agriculture. The remainder including mechanized rain-fed and traditional rain-fed agriculture is under extensive patterns of land use, about $75 \%$ of the total natural pasture is utilized by nomadic and trans human animal production systems through an enabling policy frame work, use of modern technology for increased productivity and improved rural and public physical infrastructure. The present level of productivity per man or unit land is low in both crops and livestock (Ahmed, 2009). Livestock as a system is generally incorporated within the mentioned three cropping systems. Furthermore, livestock farming takes place on natural pasture with the vast majority of the pastoralists operating on dry lands. It thriving on the rich flood plains provides the fundamental basis for wealth, status and social linkages. The rich resource setup and sea- sonal variability allows people to utilize food availability in different seasons and areas, but this depends on ability of people to move, trade, and feed their livestock. Accordingly food problems exist only when such movement is hindered due to security problems. Yet agro-climatic conditions induce high variability the extent mentioned above from bumper harvests to crop failure. Historically, considerable conflicts between herding and crop agriculture is usually occurred due to of the encroachment of herding on cropland, but it is dominantly distributed within the conventional rain-fed agriculture in the form of pastoral grazing with over-riding transhumance mode of livestock keeping. However, many sub-systems exist within these major systems. Irrigated agriculture comprises three sub-categories namely, the Gravity irrigation, Pump irrigation and Basin (Flush) irrigation as well as some small basins. The irrigated farm size in Sudan is plotted in limited areas of approximately averaged 15 feddans to tenants who are effectively under fixed rental contract with the country State. While conventional agriculture is also diverse with large areas under clay soils across central and southern Sudan and others under sandy soils in the western parts. With a total arable land of about 84 million hectare, the average area under cropping during the period 2004-2006 amounted to close to 17 million ha representing some $20 \%$ of the total arable land. The farming system of the mechanized rain-fed sub-sector is described as the largest one, it can be range from one thousand feddan escalating to 50,000 and a million feddans are leased out to individuals. The distribution of crop cultivation over the three main farming systems (Figure 1) namely irrigated, mechanized rain-fed and traditional rain-fed systems are indicated wide prevalence of traditional agriculture $(58 \%)$ and sizeable mechanized cropping (33\%). Irrigated farming, although smaller in area, assumes high importance in total value of production and contribution to the country's GDP relative to the other two sectors as shown in Figure (1). In general terms, the main crops grown in the irrigated sector are cotton, wheat, sorghum and groundnuts. The traditional rain-fed sector is dominated by sorghum in the central clay soils where sesame and sunflower in addition to limited amounts of cotton are produced. In the sandy soils of western Sudan the major crops are millet, sesame and groundnuts. On the other hand in areas of mechanized agriculture in eastern, central and western Sudan, sorghum and sesame are the major crops, but sunflower production gains increasing importance while cotton is also produced. Vegetables and fruits are found almost in all parts of the country, although they are of more importance in the northern part of the country, which is also the hub of production of cool-season food legumes such as faba bean, chickpea and lentil. Livestock production, which contributes about $20 \%$ to the total GDP, prevails all over the country under three main sub-systems. The most prevalent is transhumance animal keeping within an agro-pastoral system characterized by presence of arable farming and livestock migration in part of the season in search for feed and water. Sedentary livestock keeping is also widely spread and is more obvious under irrigated 
farming. The most intensive type of the sedentary type is the relatively modern dairy farming in urban and peri-urban locations in most parts of the country. Nomadic livestock keeping is also found in all parts of northern Sudan, but is decreasing in importance where nomads represented $3.4 \%$ of the total population in 1993 compared with about $14 \%$ in 1956 (Zarroug, 1996). In northern Sudan cropping activities are contributing significantly to the household food economy.

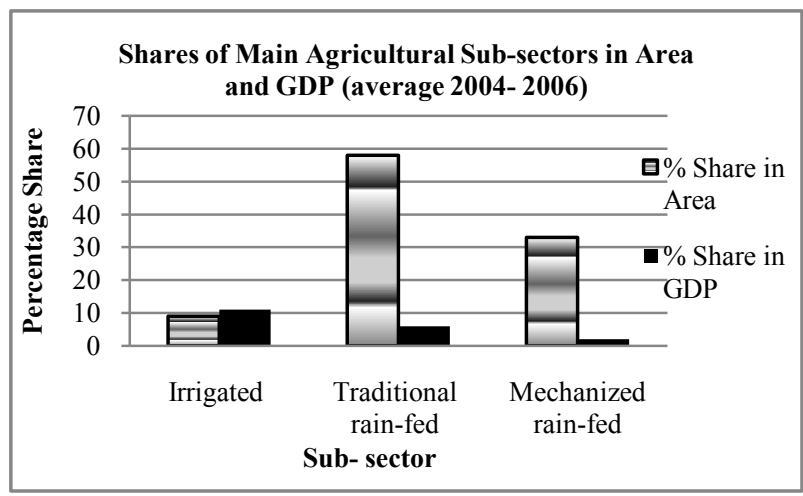

Figure 1. Percentage Shares of main agriculture sub-sectors in area and GDP

\subsection{National Agricultural Policy}

Sudan's agriculture contributed almost all the exports until the late 1990s. The emergence of oil has not just reduced their share of total exports, but has drastically reduced their absolute levels of exports. Obvious example for that are sesame and livestock exports. Their export after years of rapid growth began to fall drastically after 1999 .

\subsubsection{Scenario of Agricultural Exports Dwindling Against Oil Export}

The last decade (2000s) that the country's conventional agricultural exports are witnessed clear decline against rise of oil exportation warning decision makers for emergent reform. Careful management of the exchange rate and compensatory incentives for agriculture must be designed to forestall that possibility. Even before the emergence of oil exports, Sudan's production and export of cotton had been declining due to the official policy of encouraging self- sufficiency in food by transferring switching irrigated land from cotton as an essential cash crop to food crops by the centrally-enforced system of crop rotation. There is no evidence that this policy made any economic sense. Its implementation deprived large numbers of agricultural workers of their livelihood due to the large net reduction in labor use brought about by the shift of cultivated area from cotton to food crops. No doubt the deterioration in agricultural exports regarded as a major cause of poverty incident for a large number of conventional farm households. If the emergent institutional reform mentioned above is implemented in irrigated agriculture sub sector, the principal tool of this discrimination against cotton will be eliminated. It is however not clear if there are additional disincentives to cotton in the system of taxation, trade or input pricing. These discriminations, as indeed discrimination against agricultural products generally, especially those produced by, and/or employing, the poor, should be carefully identified and ended. The creation of monopoly in the export marketing of livestock products had an adverse effect on both productive efficiency and income distribution. Marketing Board control over export of Gum Arabic also amounts to a tax on its producers. These disincentives should be ended and replaced by the promotion of competition in marketing. Indeed, the promotion of competition in the marketing of agricultural produce and the distribution of agricultural inputs is a general principle that should be aggressively pursued.

\subsubsection{Human poverty in Sudan}

Table 1. Poverty incident in both rural and urban families in Sudan

\begin{tabular}{|c|c|c|c|c|c|c|}
\hline \multirow{2}{*}{ Year } & \multicolumn{2}{|c|}{ Percent in total } & \multicolumn{2}{c|}{$\begin{array}{c}\text { Number } \\
\text { (Million) }\end{array}$} & \multicolumn{2}{c|}{$\begin{array}{c}\text { Annual \% Change } \\
\text { in Number }\end{array}$} \\
\cline { 2 - 6 } & Rural & Urban & Rural & Urban & Rural & Urban \\
\hline 1968 & 62.7 & 15.9 & 1.18 & 0.052 & \multirow{2}{*}{3.0} & 9.3 \\
\hline 1978 & 64.2 & 20.5 & 1.58 & 0.127 & 4.9 & 14.3 \\
\hline 1986 & 83.1 & 52.9 & 2.31 & 0.370 & 2.8 & 11.3 \\
\hline 1992 & 93.6 & 84.4 & 2.73 & 0.705 & & \\
\hline
\end{tabular}

Human poverty in Sudan is particularly high among the rural people (see Table 1). The AEPRC (2009) reported that rural human poverty index (HPI) ranges from 70.8 in North Kordofan State to 29.8 in the Northern State, urban human poverty index (HPI) ranges from 39.1 in West Darfur State to 14.3 in Al Gazira State. The results also indicated that the State-level human poverty indices are not only individually high but almost equal in being high as indicated by the small rural Ginni coefficient $(\mathrm{G}=0.128)$ in contrast to the relatively big urban Ginni coefficient $(\mathrm{G}=0.152)$. For North Sudan as a whole rural human poverty index was 51.3 and urban human poverty index was 24.9 . The results revealed that the difference in magnitude between rural and urban human poverty at the State level shows that the rural human poverty index in every State is significantly greater than the urban human poverty index. Faki et al (2009) mentioned that human poverty in North Sudan was primarily a rural phenomenon dominated by deprivation in the decent standard of living. As such, anyone would have obviously recommended a rural development program being dominated by agricultural development. Again the deprivation in the decent standard of living dominates the scene of human poverty in this region as indicated by the high values (see Table 1). From Table 1 the incidence of poverty has been higher in rural areas than in urban areas as a well known phenomenon for the developing countries. The rate of increase in the incidence of poverty has however been far greater for the urban areas than for the rural areas. This is might confirms the infeasibility of farm returns as a major source of income in most of the rural people and causing migration to the urban areas. Despite the urban poverty is continued increasing over any given time period in trying to explain the different rates of performance of different crops? This 
situation may reflect the different rates of effective protection that these crops were subject to the increase in the magnitude number of the poor has been higher for rural areas than for urban areas in each period.

\subsection{Agriculture and Poverty Incident}

Relating the performance of the agricultural sector to other important aspects like poverty rates one can obviously see that, despite high growth rates of the Sudanese economy during the past years, the level of poverty has dramatically increased.

Poverty and agricultural development in Sudan estimated through the observations of rural factor markets (Pearson et $a l, 2003$ ). The (water and land resources) agricultural development potential is manifest in the large mass of productive land not yet utilized and in the favorable land/ man ratio.

\subsubsection{Agricultural Resources Use in Sudan}

The magnitude of the arable land, water and vast pastures forests qualified the Sudan for large scale crops and livestock production. UNEP (2007) reported that Sudan with its large land expanses extending over about 2.5 million $\mathrm{km} 2$ is bestowed with diverse natural resources. Agricultural activities, forming the main source of livelihood in the country, are basically geared by the magnitude of natural resources. This is particularly so on account of the low level of use of modern agricultural inputs. While soil types vary across the country, agro-ecological characteristics are largely shaped by climatic variation along its north-south axis. Rainfall is the single major component influencing natural resources and their use patterns. Rainfall increases along the north-south axis from almost null in the northern borders to over $1400 \mathrm{~mm}$ in south-western part of the country. Most of the administrative regions fall with rainfall zones characterized by the north south rainfall decrease. All their southern parts enjoy reasonable amounts of rainfall averaging approximately $700 \mathrm{~mm}$. The variability of Sudan's agro- ecological resources is reflected by Purnell and Venema (1976) identifying 16 mapped units with different agricultural potential based on the interplay of soils and climate that were further divided into 38 subclasses across the country. Rainfall is generally variable as reflected by annual variations of $45 \%$ in northern Sudan and $15 \%$ in its south and south-eastern parts (Eltom, 1996). In addition to rainfall, however variable as it is, Sudan's water resources are augmented by flows from the Nile and its tributaries, annual flows from many seasonal rivers and streams, and by underground and deep water. Utilization of most of these waters is bound with high costs due to the diverse geography and variable nature of water flows among and within years. In spite of this, a considerable potential exists to develop water resources of the country to expand irrigated areas and employ water-harvesting techniques to improve agricultural productivity; a situation congruent with objective of poverty reduction. Enormous pressures have been exerted on those agricultural resources over time. Some 50 years back land was generally far in excess of demand and natural resources were capable of sustaining the livelihood of people even under problematic land use patterns.

Hinging on the prevailing problematic land tenure system, such pressures have mounted since then and developments in human and livestock populations and arable cropping (Table 2 ), as well as deforestation have been largely behind degradation of the natural resource base. From Table (2) it is obvious that the three factors show a great increase. The high livestock growth rates are remarkable, substantially surpassing those of rural population and reflecting rising per capita livestock numbers in rural areas that can be calculated to grow annually by an average $1.66 \%$. The per capita growth rates were variable among regions, being highest in Khartoum (3.3\%) and North (3.2\%). Relatively high growth rates are also derived for the Central Region and Kordofan $(2.7 \%$ and $2.2 \%$, respectively). Rates were relatively lower in the Eastern region $(1.5 \%)$ and negative in Darfur due to migration influxes. Growth rates in terms of Tropical Livestock Units (TLU) have been slower in all regions (except the Central Region where they increased to $4.2 \%$ ), indicating a shift towards small ruminants (Faki et al, 2009). Deforestation has been significant. The FAO data shows that total forests have been reduced by 8.247 million ha, or $11.6 \%$, between 1990 and 2005. UNEP (2007) estimated the increase in deforestation at an annual rate of over $0.84 \%$ at the national level, while at the regional level, two-thirds of the forests in north, central and eastern Sudan disappeared between 1972 and 2001. In Darfur, one third of the forests cover was lost between 1973 and 2006.

Table 2. Growth in rural population, livestock wealth \& crop areas (1973-2007)

\begin{tabular}{|c|c|c|c|c|c|c|}
\hline \multirow{2}{*}{ Region } & \multicolumn{2}{|c|}{$\begin{array}{c}\text { Rural Population } \\
\text { (million) }\end{array}$} & \multicolumn{2}{c|}{$\begin{array}{c}\text { Livestock wealth } \\
\text { (million head) }\end{array}$} & \multicolumn{2}{c|}{$\begin{array}{c}\text { Crop Areas Region } \\
\text { (million feddans }\end{array}$} \\
\cline { 2 - 7 } & 1973 & 2007 & 1973 & 2007 & $\begin{array}{c}\text { Average } \\
1971-75\end{array}$ & $\begin{array}{c}\text { Average } \\
2003-07\end{array}$ \\
\hline North & 0.753 & 1.177 & 1.003 & 4.877 & 0.102 & 0.512 \\
\hline Khartoum & 0.899 & 0.731 & 0.506 & 1.310 & 0.014 & 0.185 \\
\hline Central & 2.971 & 5.241 & 7.031 & 31.603 & 31.603 & 3.915 \\
\hline Eastern & 1.228 & 2.605 & 2.472 & 8.955 & 2.544 & 6.819 \\
\hline Kordofan & 1.720 & 2.848 & 6.819 & 24.529 & 6.117 & 9.299 \\
\hline Darfur & 1.703 & 5.673 & 11.039 & 30.374 & 2.242 & 7.692 \\
\hline Total & 9.273 & 18.275 & 28.869 & 101.647 & 14.933 & 32.779 \\
\hline $\begin{array}{c}\text { Growth } \\
\text { (\%) } * *\end{array}$ & \multicolumn{2}{|c|}{1.94} & \multicolumn{2}{|c|}{2.60} & \multicolumn{2}{|c}{} \\
\hline
\end{tabular}

* 1 feddan $=0.42 \mathrm{ha},{ }^{* * A v}$. annual growth $(\%)-$ exponential growth.

UNEP indicates that forest cover could decline by over $10 \%$ per decade with total loss expected within the next 10 years in high pressure areas. The land tenure system has been a major underlying factor behind use of natural resources. Under the Land Resettlement and Registration Ordinance of 1925, which is still largely in force (De Wit, 2001), all unregistered land belongs to the government while community rights are recognized over its use under customary rules. Individual land registration is limited, while long land lease applies in public irrigation schemes and in large semimechanized rain-fed private holdings. Communal land use 
provides incentives to increase livestock herds irrationally and encourages crop expansion with almost no soil conservation measures leading to soil mining under continual relaxation of the shifting cultivation system that used to be followed in the past. De Wit (2001) summarized that still fairly balanced management of natural resources had been practiced by the traditional leadership system till its dismantling in the early 1970s. The control over natural resource management has therefore undergone profound relaxation resulting in misuse through deforestation and over-grazing.

\subsection{Agricultural Income}

Using detailed calculations from available data, the attempt is made to estimate average per capita rural income from agriculture in each of the 15 northern sates based on data availability at the state level. The estimates have been inspired by similar income assessments in Syria (Szönyi et al., 2005 and Faki et al., 2009) that were based on gross income calculations.

\subsubsection{Technique of Assessing Agricultural Income}

Income derivation here is based on gross returns from crops and livestock less intermediate inputs that mainly constitute machinery use, fuel and agricultural chemicals. The following procedures and assumptions have been adopted in the agricultural income calculations:

- Crop and livestock production data available from official statistics, mainly the Ministry of Agriculture and Forests (MAF), the Ministry of Animal Resources and Fisheries (MARF), and Ministries of Agriculture in some States), are compiled as disaggregated by State for North Sudan.

- The most recent prices are used; predominantly those prevailing in 2007 but prices of some products, especially horticultural crops and livestock have been subject to estimates based on the ruling general market prices.

- Computations are made for each crop or livestock product under each state where from the total returns per activity (production * price), costs of intermediate inputs are deducted to arrive at total income per activity per state.

- The ranges of crop products included in the assessment are as follows:

$\Upsilon$ Field crops: sorghum, millet and wheat.

Oil crops: sesame, groundnuts and sunflower.

$\Upsilon$ Winter legume crops: faba bean, beans and chickpea

$\Upsilon$ Fiber crops: cotton.

$\Upsilon$ Tree crops: gum Arabic.

$\Upsilon$ Vegetables and spices: onion, tomato, okra, eggplant, leafy vegetables, cucurbits, potato, sweet potato, and spices. Rosella 'karkade' is included in this group.

$\Upsilon$ Fruits: mango, banana, grape fruit, oranges, lemon and dates.

Total income is derived by state and, using the state-level rural population given by the Central Bureau of Statistics (CBS), average per capita incomes are derived for each of the crops and livestock categories as well as for all agricul- tural activities under consideration (see Table 3). According to the data of the Central Bureau of Statistics (CBS) the average national AgGDP for the period 2002-2006, excluding forestry and fisheries, can be computed to amount to SDG 23, 740 million. The estimated AgGDP in Table (3) of SDG15, 646 million represents about $66 \%$ of the CBS reported total.

Table 3. Estimated total and annual per capita income by state and per capita-income ranking

\begin{tabular}{|c|c|c|c|c|c|c|c|c|c|}
\hline \multirow{2}{*}{ State } & \multicolumn{3}{|c|}{$\begin{array}{c}\text { Total income } \\
\text { (SDG 'million) }\end{array}$} & \multicolumn{2}{c|}{$\begin{array}{c}\text { Average per } \\
\text { capita (SDG) }\end{array}$} & \multicolumn{2}{c|}{$\begin{array}{c}\text { Per Capita } \\
\text { Income Rank }\end{array}$} \\
\cline { 2 - 13 } & Crop & $\begin{array}{l}\text { Live- } \\
\text { stock }\end{array}$ & Total & Crop & $\begin{array}{c}\text { Live- } \\
\text { stock }\end{array}$ & Total & Crop & $\begin{array}{l}\text { Live- } \\
\text { stock }\end{array}$ & Total \\
\hline Northern & 653 & 215 & 868 & 1215 & 401 & 1,616 & 1 & 5 & 2 \\
\hline R. Nile & 580 & 181 & 762 & 909 & 284 & 1,193 & 2 & 10 & 4 \\
\hline Khartoum & 585 & 129 & 714 & 809 & 178 & 987 & 3 & 15 & 8 \\
\hline Sennar & 747 & 312 & 1,060 & 788 & 330 & 1,117 & 4 & 8 & 5 \\
\hline W. Darfur & 1,021 & 703 & 1,724 & 657 & 453 & 1,110 & 5 & 3 & 6 \\
\hline S. Krdfan & 1,013 & 722 & 1,735 & 595 & 424 & 1,019 & 6 & 4 & 7 \\
\hline Blue Nile & 241 & 784 & 1,026 & 450 & 1,463 & 1,913 & 7 & 1 & 1 \\
\hline Gedarif & 492 & 301 & 794 & 440 & 270 & 710 & 8 & 11 & 9 \\
\hline W. Nile & 273 & 705 & 979 & 359 & 925 & 1,284 & 9 & 2 & 3 \\
\hline Gezira & 1,002 & 723 & 1,725 & 331 & 238 & 569 & 10 & 13 & 11 \\
\hline Kassala & 372 & 219 & 591 & 317 & 187 & 504 & 11 & 14 & 14 \\
\hline S. Darfur & 778 & 664 & 1,443 & 300 & 256 & 556 & 12 & 12 & 12 \\
\hline N. Darfur & 355 & 449 & 804 & 256 & 324 & 579 & 13 & 9 & 10 \\
\hline N. Krdfan & 473 & 820 & 1,293 & 195 & 338 & 534 & 14 & 7 & 13 \\
\hline Red Sea & 26 & 94 & 120 & 100 & 353 & 453 & 15 & 6 & 15 \\
\hline Total & 8,611 & 7,021 & 15,638 & 444 & 362 & 806 & & & \\
\hline
\end{tabular}

Table (3) reveals income disparities and the annual per capita varying from (in SGD) 1215 to 100 for crops, 1463 to 178 for livestock, and 1913 to 453 for all agriculture activities. The corresponding averages for Sudan are SDG 444, 362 and 806.

Ranking of states indicates that North, River Nile and Khartoum enjoy the highest per capita income from crops, while North Darfur, North Kordofan and the Red Sea are at the tail of the spectrum. With regard to livestock, the Blue Nile, White Nile and West Darfur States are leading while Gezira, Kassala and Khartoum have the least per capita income. It is generally true that states having high income from crops are endowed with irrigation facilities and those having high income from livestock enjoy substantial rainfall under the pastoral system of animal keeping.

\subsubsection{Assessment of Per Capita Agricultural Income Levels}

Per capita agricultural output increased, though at a very slow rate. The headcount ratio of poverty during this period increased very little. World Bank (1992) mentioned that the growth rate of agriculture in Sudan between 1965 and 1980 to have been 2.9 per cent per year and in (1993) reported that the growth rate between 1970 and 1980 to have been 3.3 per cent per year. During the next period, between 1978 and 1986 agricultural GDP may have declined absolutely. Dur- 
ing this period per capita agricultural output appears to have fallen rather sharply. This was the period of the most rapid increase in rural poverty. The agricultural activities performed by household members significantly reduce the likelihood of being in a higher poverty status.

In contrast, the irrigated farms show that the variables that are positively correlated with the probability of being poor are the size of the household, the number of children in the household and working in a secondary occupation and being affected by diseases, while the variables that are negatively correlated with the probability of being poor are gender, the age of the household head, the education level of the household head and household members performing agricultural activities (Elzaki et al, 2010). The aggregate per capita income per day can be derived at USD 1.08 at an exchange rate of SDG 2.05 per USD. While acknowledging variation among states, the country is as a whole is close to the edge of poverty according to the average cost of the food basket computed as an equivalent $\$ 1.1$ (Faki et al, 2009). The estimated food poverty line in mechanized farms is equal to $\$ 0.17$ per day per person, while those of irrigated and traditional farms are $\$ 0.14$ and $\$ 0.34$ per person per day, respectively. Similarly, the extreme poverty line of the traditional farms is $\$ 0.41$ per person per day, whilst those of the mechanised and irrigated farms are $\$ 0.21$ and $\$ 0.16$ per person per day (Elzaki et al, 2010). The array of per capita income per day in USD for the 15 Northern States is presented in Figure (2). The range is from USD 2.56 (Blue Nile) to USD 0.61 (Red Sea). Seven states are shown by the Figure to fall below the poverty line as far as agricultural incomes are concerned. This is most likely the case since agriculture is known to provide the main livelihood source in rural Sudan. Over the period between 1986 and 1992, agricultural GDP appears to have increased modestly, at about 3 per cent per year. Per capita agricultural output increased at a moderate rate of perhaps one and a half per cent per year or more. It should however be noted that for the two years prior to 1991/92, agricultural performance was extremely bleak so that some of the output growth in 1992 must have gone to offset a part of the debts and obligations accumulated by the poor during those adverse years. Even so, the rate of increase in poverty moderated during this period. Together with the acceleration in migration to urban areas, this led to the lowest rate of increase in the absolute number of rural poor during this period (Khan, 2004). Average yields for (2006/2007) and at current prices. Although of this, presence of other income sources is highly possible such as small businesses and remittances. Figure (2) reflects the estimated average per capita agricultural income in USD at an exchange rate of SDG2.05/USD in rural areas of Sudan at On the other hand; the analysis does not allow any type of inter-state disaggregation to identify agricultural income poverty levels among various population groups who possibly undertake different agricultural activities. For instance, in almost all states that are endowed with irrigation facilities rain-fed agriculture is also practiced with varying degrees. Evidence shows that yields under the latter system are poor, but the farm size could matter as far as per capita income levels are concerned. It is to be noted that, while the low-income states include those that are usually reported to have high poverty levels, namely North Kordofan, Kassala, Red Sea and North and south Darfur, estimates also reveal income poverty in the rural areas of Gedarif and Gezira States, which have until now been considered to remain outside the poverty zone. In the Gezira State, this is likely to be a result of the enormous restructuring challenges that have been facing the Gezira Scheme in recent years, which is the major source of agricultural income in the State with a tremendous area of two million feddan. Gedarif, even with its known lead in producing sorghum and sesame, has been prone to low and deteriorating crop productivity and low prices of the crops produced. Income poverty in Gedarif might be higher than denoted by the figures if it is taken into consideration that the state is highly dominated by semi-mechanized crop production in the hands of big investors, with limited spill-over income effect to small rural households. It is also worth noting that Khartoum, which might be considered as a relatively favored state, its rural part is not far away from the fringes of poverty.

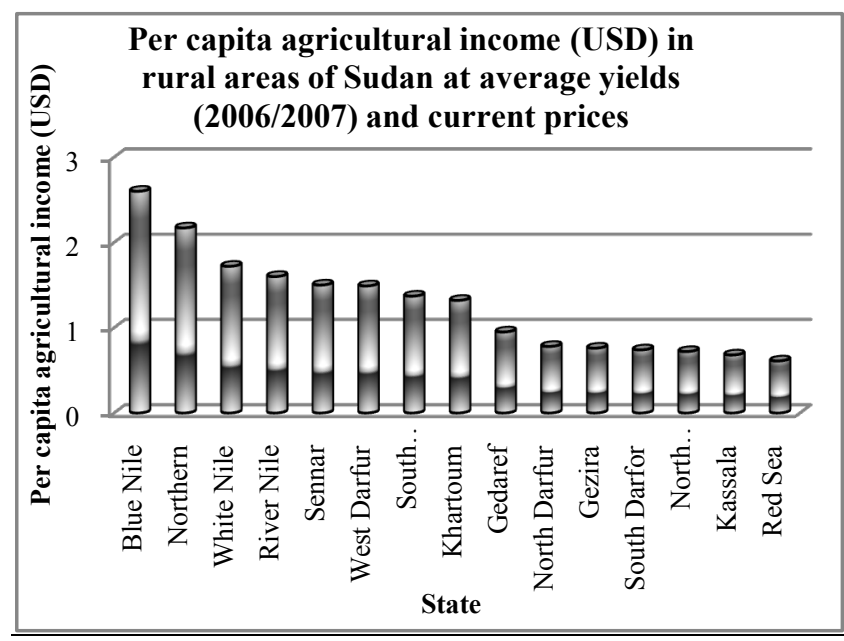

Figure 2. Estimated average per capita agricultural income (USD)* in rural areas Sudan at average yields for (2006/07) and current prices

The whole situation might be indicative of temporal spread of poverty in Sudan's rural areas. It is also worth noting that the estimates confirm that the frequently mentioned problems in the Blue Nile, West Darfur and South Kordofan are in fact a product of instability due to civil conflict rather than poor resource productivity; a situation that is also evident from the earlier-displayed analysis of human poverty indicators. These areas are relatively rich in land and water resources and accommodate sizeable crop and livestock activities that provide decent incomes relative to the size of their rural population. The Blue Nile State is favored with high rainfall and rich land cover. It hosts a variety of crops and forestry resources while its boasts of considerable livestock wealth. West Darfur, with its reasonable rainfall, its mild weather as influenced by the Jebel Mara Plateau and its land abundance hosts a range of agricultural activities including horticultural crops that provide 
satisfactory incomes. However, the area has been negatively affected by high influx of people moving from neighboring countries, being encouraged by abundant land and relatively rich resource endowments and putting high pressure on its natural resources (van Hollst Pellekaan, 2007). South Kordofan also enjoys rich natural resources and the estimated figures of per capita income are most likely reduced by the effect of joining part of the former West Kordofan State to South Kordofan in 2007 while the other part went to North Kordofan. It is yet to be mentioned that these states, especially South Kordofan and Blue Nile. In addition to Gedarif, Sennar and White Nile accommodate large expansions of mechanized farming with big holdings in which mostly sorghum and sesame are grown. The income distribution would therefore be highly affected by that from these large holdings, resulting in high income skewness. Accordingly, the per capita incomes derived in these states might hide more spread poverty than depicted from the figures. Thus should bear in mind that an increase in agricultural output per capita alone is no guarantee for the avoidance of increased impoverishment. Another physical evidence that the personal income of the rural households may have failed to grow at the same rate as agricultural output due to the deterioration in agriculture's terms of trade or due to a slower increase in household income from non-agricultural sources. The distribution of rural income may also have changed adversely for the poor (see Table 4)

Table 4. Poverty rates by residence and sector of employment

\begin{tabular}{|c|c|c|}
\hline Residence: & $\begin{array}{c}\text { Population below } \\
\text { poverty line (1990) }\end{array}$ & $\begin{array}{c}\text { Population below } \\
\text { poverty line (1996) }\end{array}$ \\
\hline Rural & 75.4 & 94.8 \\
\hline Urban & 79.6 & 81.4 \\
\hline \multicolumn{3}{|c|}{ Sector of Employment: } \\
\hline Agriculture & 76.0 & 96.1 \\
\hline Industry & 79.9 & 83.3 \\
\hline Services & 78.1 & 85.4 \\
\hline
\end{tabular}

\subsubsection{Interface of Income, Agriculture And Human Poverty}

The socioeconomic characteristics of rural poor households are expected to have great effects on the poverty incidences in the study areas. The educational attainment of the head of the household is found to be among the important factors associated with poverty (Elsheikh and Siwar, 2004; Chadha, 2002; Dasgupta, 1989). The majority of the poor rural household heads are illiterate. The estimated illiteracy in the irrigated farms $(68.1 \%)$ and traditional farms $(62.5 \%)$ are more than those in the mechanized farms (49.3\%) (Elzaki, 2010). To bring the three indicators together, it becomes inevitable to go for computations per region as a common denominator. Table (5) gives the ranking of the six northern regions according to each indicator. The highest number of rural poor people is found in the traditional farms (91\%), followed by the mechanized farms $(85.4 \%)$ and the irrigated farms $(66.7 \%)$. Poverty in rural Sudan over 2005-2006 had been more widely spread and deep in traditional and mechanized farms than in the irrigated farms.

Table 5. Ranking of regions in North Sudan according to income, agricultural and human poverty indicators

\begin{tabular}{|c|c|c|c|c|c|c|}
\hline \multirow{2}{*}{ Region } & \multicolumn{3}{|c|}{ Income (1996) } & \multicolumn{2}{|c|}{ Agricultural (2007) } & \multirow{2}{*}{$\begin{array}{r}\text { Human } \\
(2006) \\
\text { Rank }\end{array}$} \\
\hline & Indicator1 & Rank & Indicator 2 & Rank & Indicator 3 & \\
\hline Darfur & 97 & 1 & 1.0 & 2 & 51.1 & 1 \\
\hline Kordofan & 96 & 2 & 1.0 & 3 & 47.4 & 2 \\
\hline Eastern & 94 & 3 & 0.7 & 1 & 43.3 & 3 \\
\hline Northern & 93 & 4 & 1.9 & 6 & 24.4 & 5 \\
\hline Central & 91 & 5 & 1.6 & 5 & 34.4 & 4 \\
\hline Khartoum & 80 & 6 & 1.3 & 4 & 14.3 & 6 \\
\hline
\end{tabular}

$1=$ poverty incidence; $2=$ per capita agricultural income; $3=\mathrm{HPI}$

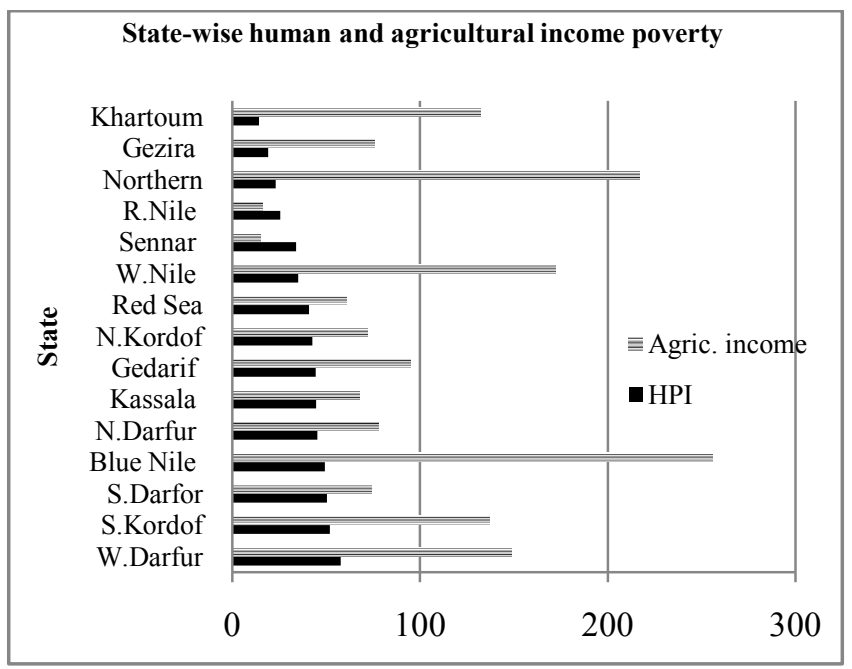

Figure 3. State-wise human, agricultural income poverty and their ranking HPI Agric. State Level Rank Level Income Rank

The variations in the standards of living and the incidence of poverty are particularly related to the differences in agro-climatic/geographical conditions (Gunasena, 2003). Table (3) shows that income and human poverty are seemed to go together, except for the slight reversal in the Central and Northern Regions. Agricultural poverty is in line with both income and human poverty where Darfur, Kordofan and Eastern Regions are poorer than the remaining regions. On the other hand, Khartoum is more disadvantaged from the agricultural side, while the Eastern Region is the most agriculturally disadvantaged region as compared with its somehow better position in human and income gains. Generalization over regions is not accurate, since for example in the Eastern Region it can be argued that Gedarif State is agriculturally better-off than Kassala, which is in turn better-off than the Red Sea State. Yet overall, it is evident that high interactions exist among the three poverty components, indicating that integrated development is essential if poverty in all its measurable indicators is to be reduced. On the other hand, state-wise comparisons are made with respect to agricultural and human poverty indicators. This is illustrated in Figure (3) in which ranking according to incomes from agriculture (in $\$$ cent) are superimposed on the ranking with 
respect to human poverty in descending order. Four states (lightly shaded) have relatively lower position as far as both agricultural and human poverty indices are concerned. These are South and North Darfur, Kassala and Gedarif. In these states both human and agricultural income developments are needed. Another four states (shaded darker) encounter relatively less deprivation in both measures. These are White Nile, Sennar, River Nile and the Northern States and may have a delayed priority in interventions. Other states have variable stands. West Darfur, South Kordofan and Blue Nile have higher human deprivation and accordingly require more input in this area.

North Kordofan, Red Sea and Gezira States suffer more from agricultural poverty although their human poverty status is somehow moderate except for Gezira where human deprivation is relatively low. In those states promotion in agriculture is more urgent. Khartoum is a special case where agriculture needs some push. Many studies have shown that occupational categories affect the depth of poverty (Dreze et al., 1992; Angelsen and Kaimowitz, 1999). The contribution of various agricultural activities to agricultural incomes varied from state to another, but one striking feature is the dominance of livestock in contributing to total income from agriculture in most states. Especially high contributions are evident for the Red Sea, Blue Nile, White Nile and North Kordofan, ranging from 78 to $63 \%$. On the other hand, such contributions are relatively low in the Northern, River Nile, Khartoum and Sennar ranging between 18 to about $30 \%$ of the states with per capita income per day higher than USD1, dependence is high on livestock in the Blue Nile and White Nile State, and on horticultural crops and legumes in North and River Nile States, although cereals have notable contribution in the River Nile state (Faki et al, 2009). Livestock contributions are tangible in numerous States namely, West Darfur and South Kordofan, but along with Sennar and Khartoum, horticultural crops have generally significant shares. Except for North Darfur and Red Seas, the bulk of income in the states below the USD1.1 threshold is generated from cereal and oil crops in contrast to the higher-income group of states where these sources are of lower contributions. The share of horticultural crops is sizeable within this group, especially in Kassala with respect to both vegetables and fruits) and in North Darfur with respect to vegetables where relatively high production of cucurbits, tomatoes and okra is reported. It can therefore be argued that horticultural crops and cool-season food legumes, in addition to a well-managed livestock production could form important options to raise incomes in these states.

\subsection{Crop Yield Volatility and Poverty Incident}

Agricultural resources productivity of crops especially land and water form an important factor influencing spatial distribution of incomes and poverty in various states. Further, it is clear that farm size and agricultural production costs are another two essential components to crop productivity to determine incomes and poverty levels. The contribution of various agricultural activities to agricultural incomes varied from state to another. The most dominant cash and food crops existed overall the country States are cereals, oil crops, cotton, gum Arabic, legumes, vegetables (including spices and rosella 'karkade'), fruits (including dates) beside livestock. The share of horticultural crops is sizeable within this group, especially in Kassala State with respect to both vegetables and fruits) and in North Darfur with respect to vegetables where relatively high production of cucurbits, tomatoes and okra is reported. It can therefore be argued that horticultural crops and cool-season food legumes, in addition to a well-managed livestock production could form important options to raise incomes in these states. All these activities require a good market structure that enables efficient movement of products to consumption centers. Further, and except for Gezira, the low-income states are characterized by lower availability of the water resource compared with the high income states.

The situation is implying the importance of providing higher investments in sourcing water for agriculture. Figure (4) shows assessment of yields volatility per unit area of the major crops in various states over two 5-year time periods: 1970/71-1974/75 and 2002/03-2006/07 listed according to the poverty ranks shown earlier.

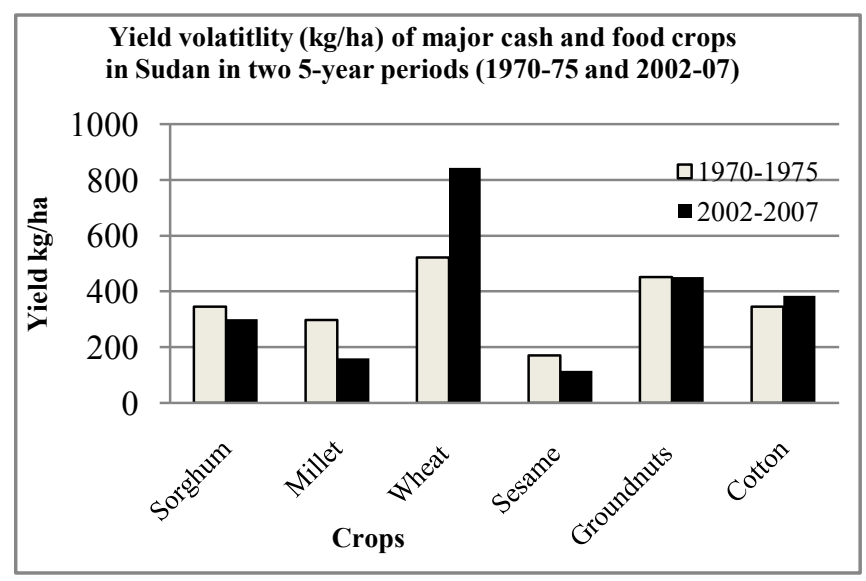

Figure 4. Yield volatility (kg/ha) of major crops in Sudan over two 5-year periods: 1970/71-1974/75 and 2002/03-2006/07

Assessment of yields volatility are limited to the cases where yield data is available simultaneously for the two periods, since there have been changes in the crop mix in some situations and data limitations in a few others. The average figures show clearly declining yields for sorghum, millet, sesame and groundnuts, which are either fully or largely rain-fed. Yields of irrigated crops (wheat and cotton) depict a rising mode due to higher certainty of soil moisture and use of better technology. Especially tremendous improvements are evident for wheat attributed to strong government backing. However, relative volatility in yields over the two periods in the 15 states is depicted in Figure (5) (also listed in the same order of agricultural income levels). Averages yield volatility for different crops in each state are weighted by their respective area averages over the two periods (1970/71-1974/75 and 2002/03-2006/07). From 
Figure (5) the productivity pattern can be argued to match the order of incomes, with some justifiable exceptions. Numerous researches mentioned that the misuse of resources, lack of appropriate technologies and finance and climate change were the important factors that led to yield volatility and thus low returns from farming and persistent poverty among the rural poor. The negative yield change for the Blue Nile and White Nile are managed by farmer to exceed the bottle neck by compensating for high incomes from livestock as mentioned earlier, while the positive, but negligible yield rise in the Red Sea is most likely confined to the limited areas (i.e. Tokar Delta). On the other hand, North Darfur encountered the highest yield reduction, but again it has a relatively better rank with respect to livestock. Gezira's modest yield improvement was mainly due to improvement in sorghum and wheat yields but probably the interaction of high production costs and lower yields of cotton and groundnuts resulted in an under-proportional income shift.

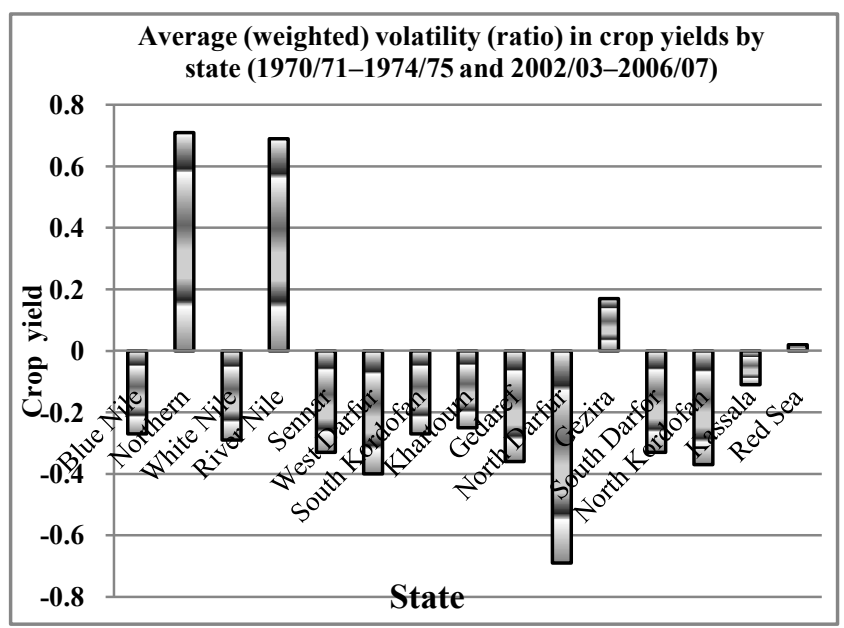

Figure 5. Average (weighted) volatility (ratio) in crop yields by state (1970/71-1974/75 and 2002/03-2006/07)

Further, all the states from Gedarif to the Red Sea fall within the low income category (less than $\$ 1.1 /$ day) illustrated by Figure (3). Faki et al (2009) mentioned that the cereals both wheat and sorghum yields show a declining trend over the income-ranked spectrum of Sudan's states, except for the lower wheat yields in the White Nile and the small increase in sorghum yields in Gezira. Millet yields are generally low, but are generally lower in low-income states except for in the Red Sea where the crop is grown in limited areas in Tokar Delta. For oil seeds (including cotton) sesame yields are generally low and volatile among states but in low-income states they are somehow lower than or similar to high income states. Overall, higher yields are clearly realized under irrigation for both crop groups but their levels are probably not high enough to offset the high production costs. Yield volatility in the conventional agricultural system is more obviously as shown in Figure (6). The increase so sharply between 1990 and 1996, while1995/96 crop year witnessed a sharp fall in crop yield of all major crops. Crop yield per feddan in the conventional agricultural system (i.e. traditional and mechanized rain-fed systems) does not differ systemically for sorghum, the overwhelmingly important crop in mechanized sector, or for sesame, the next most important crop in the sector (see Figure 6). Generally, the poverty and crop yield development in Sudan results indicate that the poor households own agricultural land, but lack the appropriate technology and the removal of subsidies from production inputs (e.g., from fertilizers, fuel), which make these the main factors for yield volatility and hence being poor in these farms. Most of the agricultural resources especially land and water are not utilized efficiently to satisfy the rural households' needs. While the potentiality of the physical crop productivity levels under the available resources and the prevailing management practices is tremendous, such potential can be better exploited by technological improvements.

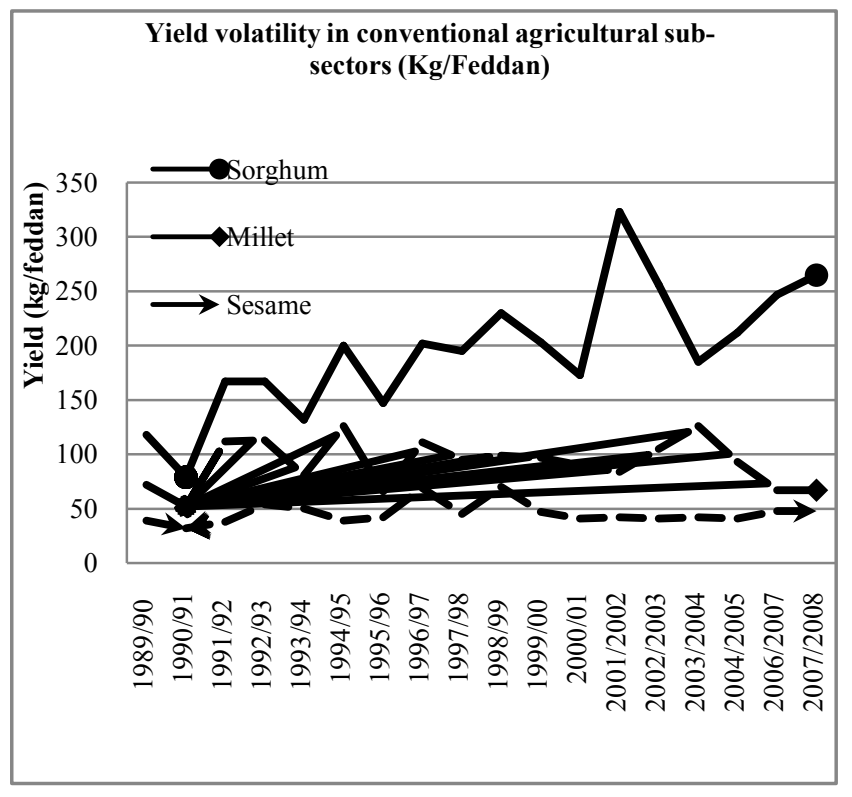

Figure 6. Yield volatility in conventional agricultural sub-sectors $(\mathrm{kg} / \mathrm{fed})$

Evidence has shown that improved technology is conducive to substantial yield improvements under different regions and production systems. Adapting and analyzing the research data, Samar Shams Elddin (2008) evaluated yield gaps between yields realized under different stages of technology testing and those obtained by farmers for a number of crops in different states (see Figure 7). Figure (7) shows average yield gaps (marginal percentage increase) between on-farm trials and actual average farmers' yields over the 1985/1986-2004/2005 for a number of crops in some of the states that are reflected by the above analysis to have low per capita income from agriculture. Enormous potential exists to raise crop yields by bridging at least part of the gaps that vary from $46 \%$ to as high as $566 \%$. Irrigated crops in the Gezira can be improved by respective margins of about $50 \%$ for wheat and groundnuts and by over $140 \%$ for cotton and sorghum. Even higher potential exists for crops under rain-fed farming where potential margins are around $100 \%$ in Gedarif and vary from 1.27 to over five-folds in North Kordofan. Exploitation of technological opportunities provides plausible means to reduce poverty. 


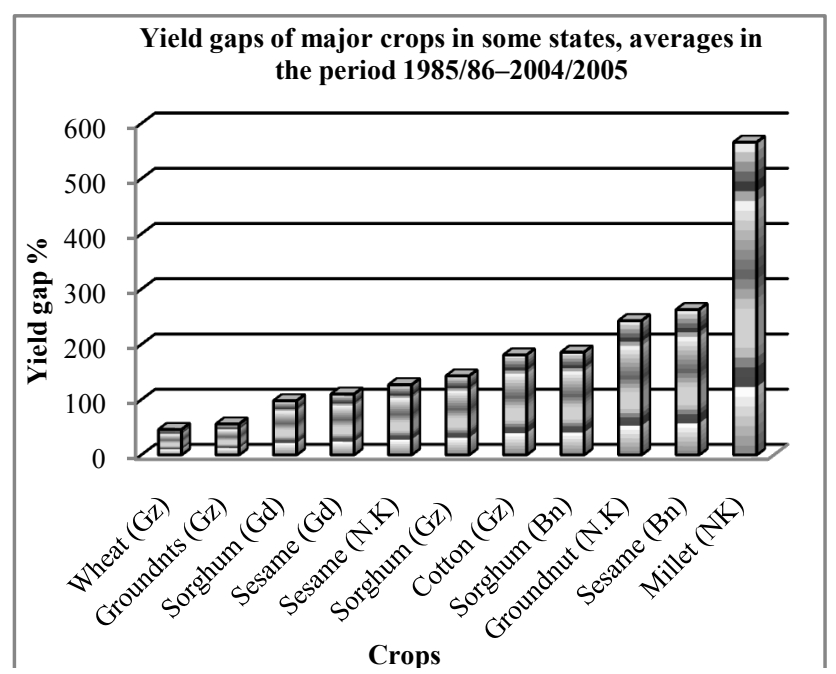

Figure 7. Yield gaps of major crops in some states, averages in the period 1985/86-2004/2005

\section{Conclusions}

Rising crop yield volatility could have important implications for poverty vulnerability. Crop yield volatility in Sudan could increase drastically in different agricultural sub- sectors especially the conventional one that dominated at the rural areas in comming future as poverty incident expected to become increasingly volatile as well. The paper unveiled that highly significant proportions of the rural population in the conventional farms are living below the poverty line suffering all forms of deprivations where poverty is sensitive to both food and cash crop.

It also revealed that the incidence of poverty is differed considerably according to State. The diverse of poverty incidences may be due to inequalities distribution of economic growth and severe disparities in manipulation of deprivation (i.e. access to education, clean water, natural resources and public services).The research addresses generally this relation between them to derive the poverty responses and to assess its various indicators within the different periods under study and the agricultural contribution to the economic growth in the country including, assessment of the current human poverty in Sudan, the national agricultural policies and squeezed scenario of agricultural exports deterioration againist non-agricultural exports. The paper also deals with government expenditure on agriculture development. It delineates with the current situation of agricultural resources use, dominant farming systems and Interface of income, agricultural and human poverty incident considering crop yield volatility to enable the policy makers to determine how the distribution of poor households of agricultural sub-sectors and volatiles attributable to crop yields volatility during coming decades and how could change in the future and designing the relevant strategies and programs. However, to promote this situation to meet the future challenges, it is requisite for the country to plan for capacity building efforts to focus on designing a relevant research and enhancing the performance of the agricultural policy. In addition, tremendous efforts needed to assault poverty incident into economic development policies and strategies. Furthermore, it is necessary a greater accessibility to a comprehensive detailed food and cash crop yields volatility and poverty incident data especially among poor households of agricultural sub-sectors. The paper results also showed that introduction of advanced technology and input subsidies is become essential particularly in the conventional agricultural sub-sector, which is considered as one of the biggest agricultural sub-sector for agricultural development and hence in reducing poverty incidence in Sudan.

\section{Recommendations}

Based on the study findings, important recommendation for future priorities in poverty alleviation have appeared and could be handled by the Federal Ministry of Agriculture and Forest and Ministry of Economic and Finance to achieve better stander living for poor households especially in vulnerable households in agricultural sub-sectors of the country (i.e. those under the poverty line). Accordingly, the paper is proposed the following recommendations:

- Introduction of suitable advanced technologies and usage of modern agricultural inputs conventional agricultural systems. Evidences have shown that they are conducive to substantial yield improvements and to avoid yield volatility under different agricultural sub-sectors and different production systems will increase the levels of incomes and reduce poverty incident.

- Promotion of agricultural research sectors.

- Increase the public and financial sector lending to the agriculture sector.

- Widespread institutional reform is needed to increase agricultural investment and to create farming entrepreneurs to lead agricultural development in each of the three farming systems.

- Provision of extra occupations (off-farm income) for poor households farmers more social services will increase likelihood of being in a low poverty status.

- Raising awareness of rural societies.

- Promotion of social harmony and equity to avoid Civil war and environmental instability.

- Setting up a system of generating information for poor households such as household income and expenditure possibly expanded to cover basic information concerning costs and returns of household farms and non-farm activities.

\section{ACKNOWLEDGMENTS}

I am thankful to Alla Almighty for the health and the strength to conduct this study. I express my deep appreciation to my colleagues Prof. Jamalludin Sulaiman and Dr. Saidatulakmal Mohd for their valuable assistance and comments during the course of the study. I am indebted and 
grateful to the Agricultural Economics and Policy Research Center in Sudan for their great encouragement during the study period.

\section{REFERENCES}

[1] Ahmed, E.A., 2009, Economic Aspects and Water Use Efficiency in Elzeidab and Elketiab Schemes of the River Nile State- Sudan. Ph.D. Thesis, University of Khartoum

[2] Angelsen, A. and Kaimowitz, D., 1999, Rethinking the Causes of Deforestation: Lessons from Economic Models, The International Bank for Reconstruction and Development/ The World Bank, The World Bank Research Observer, Vol. 14, No. 1

[3] Chadha, G.K. (2002). 'Indian agriculture in the new millennium. Human response to technology challenge', Presidential Address, 62nd Annual Conference of the Indian Society of Agricultural Economics, New Delhi, India

[4] Dasgupta, B., 1989, Diffusion of Agricultural Innovations in Village India, New Delhi: Wiley Eastern

[5] De Wit, Paul V., 2001, Legality and legitimacy: A study of the access to land, pasture and water; Sudan. A study financed by the European Community; prepared for the IGAD Partner Forum Working Group on Planning for Peace in Sudan by the Food and Agriculture Organization of the United Nations; Draft, FAO 2001

[6] Dreze, J., Lanjouw, P. and Stern, N., 1992, 'Economic mobility and agricultural labour in rural India: a case study', Indian Economic Review, India

[7] DTIS, 2008, Sudan: Revitalizing Non-Oil Exports. Diagnostic Trade Integration Study (DTIS) for the Integrated Framework Program. Study prepared by the World Bank and other international agencies in collaboration with Sudan's Commission for WTO Affairs (CWTOA), June 2008

[8] Elbashier, A. and Faki, H. M., 2006, The Role of agriculture in Poverty Reduction and Food Security in the Sudan. Draft for Review (2006)

[9] Elsheikh, S. and Siwar, C., 2004, Tenant Households and Poverty in the Gezira Irrigated Area, Sudan: Analysis and Implications, Faculty of Economics, University Kebangsaan, Selangor, Malaysia

[10] El-Solh, C.F., 2003, Gender, Poverty and Employment in the Arab Region, National Policy Group Policy Integration Department, International Labour Office, Geneva

[11] Eltom, Osman, 1996, Irrigation and water resources; In: Proceedings of the AgriculturalConference, Ministry of Agriculture and Forests, 3-2 March 1996, Khartoum

[12] Elzaki, R., Elamin, E., Ahmed, S., 2010, International Journal of Sudan Research, Vol. 1, No. 1, 2010 Poverty and agricultural development in Sudan

[13] Faki, H., and van Holst Pellekaan, J., 2009, Sudan DTIS: Trade in agricultural products, the World Bank

[14] Faki, H. M., Eltahir M. N., and Abdelaziz A. H., 2009, Poverty Assessment and Mapping in the Sudan. Joint Poverty
Progress Report prepared by the Centre for Agricultural Research in the Dry Areas (ICARDA) and Agricultural Economics and Policy Research Centre (AEPRC), Agricultural Research Corporation (ARC), Sudan. Poverty Assessment in Sudan IFAD Grant 961. Final Draft of Progress Report of North Sudan

[15] Gunasena, H.P.M., 2003, Food and Poverty: Technologies for Poverty Alleviation, Council for Agriculture Research \& Policy (CARP), Sri Lanka

[16] ICARDA and AEPRC, 2009, Poverty Assessment and Mapping in the Sudan. Joint Poverty Progress Report prepared by the Centre for Agricultural Research in the Dry Areas (ICARDA) and Agricultural Economics and Policy Research Centre (AEPRC),Agricultural Research Corporation (ARC), Sudan. Poverty Assessment in Sudan IFAD Grant 961. Final Draft of Progress Report of North Sudan

[17] Khan, A. R., 2004, Agriculture Development and Poverty Reduction In Sudan. An Analysis of Performance, Policies and Possibilities. University of California, Riverside, Final Draft. Revised 30 May 2004, A Paper Prepared for the UNDP Project on "Macroeconomic Policies for Poverty Reduction in Sudan"

[18] Pearson, S., Gotsch, C. and Bahri, S., 2003, Applications of the Policy Analysis Matrix in Indonesian Agriculture, p.104

[19] Purnell M.F. and J.H. Venema, 1976, Agricultural potential regions of the Sudan. UNDP Project for Strengthening the Soil Survey (SUD/71/553) Project Working Paper. Ministry of Agriculture, Food and Natural Resources, Democratic Republic of Sudan

[20] Shams, E. S., 2008, The Effect of Technological Production Package on the Yields of Major Crops In Sudan During Seasons 1985/1986-2004/2005. Draft Annual Report 2007, Agricultural Economics and policy Research Center, Agricultural Research Corporation

[21] SSCCSE (Southern Sudan Centre for Census, Statistics and Evaluation) (undated).Southern Sudan Livelihood Profiles: A Guide for Humanitarian andDevelopment Planning. Parklands Nairobi

[22] Szönyi, J.A., E. De Pauw, A. Aw-Hassan, R. La Rovere and B. Nseir, 2005, Mapping agricultural income distribution in rural Syria: A case study in linking poverty to resource endowments. International Center for Agricultural Research in the Dry Areas (ICARDA), Aleppo, Syria

[23] UNDP, 1997, Human Development Report

[24] UNDP, 2004, Agriculture Development and Poverty Reduction in Sudan, an Analysis of Performance, Policies and Possibilities. Final Draft Report, Revised 30 May 2004

[25] UNEP, 2007, Sudan Post Conflict Environmental Assessment. United Nations Environment Programme, Nairobi, KENYA

[26] World Bank, 1992, World Development Report 1992 shows the growth rate of agriculture between 1965 and 1980 to have been 2.9 per cent per year

[27] World Bank, 1993, World Development Report 1993 shows the growth rate between 1970 and 1980 to have been 3.3 per cent per year

[28] World Bank, 2008, Sudan. Revitalizing non-oil exports Diagnostic Trade Integration Study (DTIS) for the Integrated 


\section{Framework Program}

[29] Zarroug, Mahgoub, 1996, The pastoral sector: current situa- tion and development prospects. In: Proceedings of the Agricultural Conference, Ministry of Agriculture and Forests, 3-2 March 1996, Khartoum (in Arabic) 